\title{
Model-based estimation of pesticides and transformation products and their export pathways in a headwater catchment
}

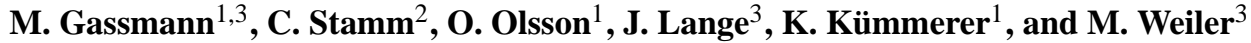 \\ ${ }^{1}$ Chair of Sustainable Chemistry and Material Resources, Leuphana University of Lüneburg, Lüneburg, Germany \\ ${ }^{2}$ Swiss Federal Institute of Aquatic Science and Technology (Eawag), Dübendorf, Switzerland \\ ${ }^{3}$ Chair of Hydrology, University of Freiburg, Freibung, Germany \\ Correspondence to: M. Weiler (markus.weiler@hydrology.uni-freiburg.de)
}

Received: 11 July 2013 - Published in Hydrol. Earth Syst. Sci. Discuss.: 26 July 2013

Revised: 25 October 2013 - Accepted: 25 November 2013 - Published: 23 December 2013

\begin{abstract}
Pesticides applied onto agricultural fields are frequently found in adjacent rivers. To what extent and along which pathways they are transported is influenced by intrinsic pesticide properties such as sorption and degradation. In the environment, incomplete degradation of pesticides leads to the formation of transformation products (TPs), which may differ from the parent compounds regarding their intrinsic fate characteristics. Thus, the export processes of TPs in catchments and streams may also be different. In order to test this hypothesis, we extended a distributed hydrological model by the fate and behaviour of pesticides and transformation products and applied it to a small, well-monitored headwater catchment in Switzerland. The successful model evaluation of three pesticides and their TPs at three sampling locations in the catchment enabled us to estimate the quantity of contributing processes for pollutant export. Since all TPs were more mobile than their parent compounds (PCs), they exhibited larger fractions of export via subsurface pathways. However, besides freshly applied pesticides, subsurface export was found to be influenced by residues of former applications. Export along preferential flow pathways was less dependent on substance fate characteristics than soil matrix export, but total soil water flow to tile drains increased more due to preferential flow for stronger sorbing substances. Our results indicate that runoff generation by matrix flow to tile drains gained importance towards the end of the modelling period whereas the contributions from fast surface runoff and preferential flow decreased. Accordingly, TPs were to a large extent exported under different hydrological conditions than their PCs, due to their delayed formation and longer halflives. Thus, not only their different intrinsic characteristics
\end{abstract}

but also their delayed formation could be responsible for the fact that TPs generally took different pathways than their PCs. We suggest that these results should be considered in risk assessment for the export of agricultural chemicals to adjacent rivers and that models should be extended to include both PCs and TPs.

\section{Introduction}

Following their application, pesticides are largely retained in the field and degraded. Only a small proportion - usually less than a percent (Leu et al., 2004a) - is transported to adjacent streams and rivers. However, this small fraction may be enough to be harmful for aquatic organisms, either by long-term exposure at low concentrations or acute exposure at high peak concentrations (Cold and Forbes, 2004) or both. Moreover, pesticides are often only partially degraded and the emerging transformation products (TPs) are ubiquitous in the environment (e.g. Olsson et al., 2013). The drawback of incomplete mineralisation is that TPs are often more mobile than their parent compound (PC), can be more persistent and occasionally even more toxic (Boxall et al., 2004). Thus, while the contamination potential of the PC declines, total contamination of the catchment system may rise due to the formation of TPs.

A variety of hydrological processes are able to mobilize both pesticides and TPs and transport them from their application point or area of formation towards the river as diffuse pollution source (Tang et al., 2012). Surface runoff was shown to be a major pathway of river contamination by 
pesticides (Schulz, 2001). Especially the first rainfall-runoff events after pesticide application are able to mobilize large amounts (Shipitalo and Owens, 2003). Under baseflow conditions, Kalkhoff et al. (2003) found only low concentrations of applied pesticides but significantly higher concentrations of TPs. Johnson et al. (1996) showed that lateral subsurface flow may contribute significantly to total pesticide transport. The effects of soil macropores for fast preferential solute transport towards tile drains were highlighted by several studies (Kladivko et al., 1991; Traub-Eberhard et al., 1994; Zehe and Flühler, 2001). Tile drains may act as short circuits for pesticide transport and were shown to be a major loss pathway (Brown and van Beinum, 2009; Doppler et al., 2012).

However, the routes of pesticide movement in a catchment are not solely governed by water flow pathways, but also by the physico-chemical characteristics of the specific molecule (Brown and van Beinum, 2009) and their interaction along the flow pathway. The most important substance characteristics governing the fate of pesticides in the environment are sorption and transformation (Arias-Estévez et al., 2008). Sorption regulates the mobility of a substance. Higher sorption comes along with higher retention because of lower mobility and thus it is less likely that sorptive substances are transported from the location of application or formation. Still, adsorbed substances may be transported attached to eroded soil particles (Hladik et al., 2009). Transformation affects the amount of a PC and TP being available for export in a catchment. Transformation kinetics and pathways are generally different in different environmental compartments like soil, plant and air and for different processes and compounds (PPDB, 2009).

Environmental fate of pesticides starts frequently with pesticide application on an agricultural field. Pesticides applied to the soil surface reach a rather thin upper soil layer, which was found to be in the range of millimetre to centimetre (Ahuja et al., 1981). Since this layer interacts with runoff by sorption processes it is often called mixing layer and contributes to dissolved or adsorbed pesticide concentration in runoff. The partitioning between dissolved and adsorbed pesticides is usually calculated using sorption isotherms. Additionally, Gouy et al. (1999) highlighted the importance of desorption kinetics (i.e. the velocity of desorption) as a limiting factor for export of pesticides by surface runoff. In fact, the hysteresis of the sorption isotherm found by many researchers may be affected by sorption kinetics (Limousin et al., 2007). The quantity of pesticides and TP infiltration into the soil matrix and deeper soil layers is strongly depended on sorption strength. Infiltration into preferential flow pathways greatly reduces sorption due to less contact area with soil and less contact time (Singh et al., 2002). Still, sorption even occurs during fast macropore transport and especially in small macropores (Jarvis, 2007).

Using process-based models is one possible way to distinguish between different export pathways since export path-

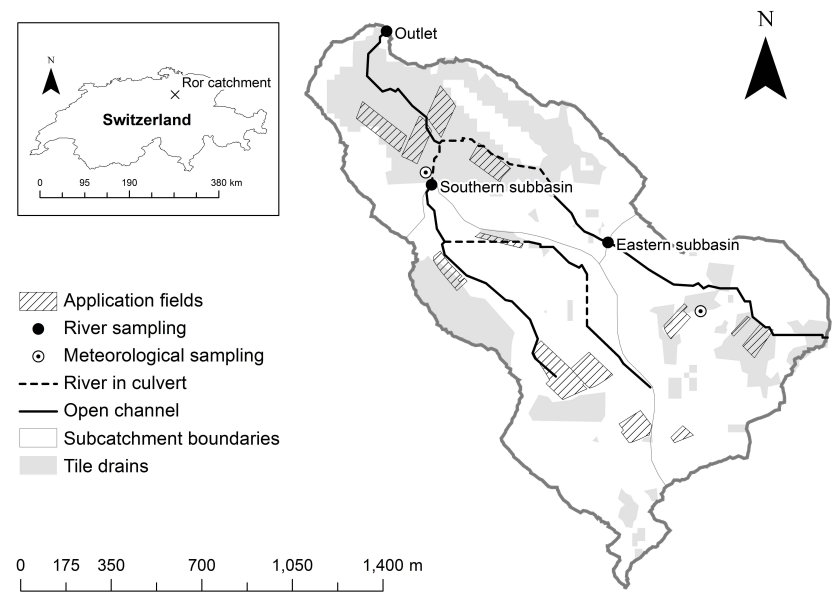

Fig. 1. The Ror catchment with pesticide application fields and artificially drained areas (swisstopo (Art. 30 GeoIV): 5704 000 000/DHM@2003, reproduced with permission of swisstopo/JA100119).

ways may be represented separately. Craig and Weiss (1993), for example, used a non-calibrated GLEAMS (groundwater effects of agricultural management systems) model in order to differentiate surface and subsurface export of pesticides towards a river. Holvoet et al. (2008) estimated the fraction of pesticide spray drift in runoff using a modified SWAT model. However, the validation of contributions from each export pathway remains a problem. Therefore, most modelling studies solely concentrated on the total amount or concentration of pesticide exported from a catchment (e.g. Flanagan et al., 2008 using AnnAGNPS model, Kannan et al., 2006 using SWAT model). Additionally, catchment scale models only considered PCs and neglect TPs. Currently, only leaching models are able to simulate the dynamic formation and fate of TPs (e.g. Ma et al. (2004) and Fox et al. (2007) using RZWQM model; Rosenbom et al. (2009) using the MACRO model).

Considering the fact that TPs have generally different environmental fate characteristics and different zones of application/formation than their parent compounds, TPs may also have different export pathways towards a river. In order to test this hypothesis, we use a process-based hydrological model that is able to separately simulate lateral matrix and macropore flow, tile drain flow fed by soil matrix or preferential pathways and overland flow to the river. The model was extended to estimate reactive pesticide transport including sorption and degradation and formation of TPs. The extended model was applied to a well-monitored Swiss headwater catchment and dominant pathways were analysed. 


\section{Methods}

\subsection{Study site}

The Ror catchment $\left(1.95 \mathrm{~km}^{2}\right)$ is located in the Swiss Plateau and has gentle slopes with altitudes between 489 and $554 \mathrm{~m}$ a.s.l. (Fig. 1). The majority of the catchment is agriculturally used $(90 \%)$ and underlain by tile drains. The bedrock consists of tertiary alluvium in the northeastern part and moraine material in the rest of the catchment (Leu et al., 2004a). Details about the soils can be found in Frey et al. (2009). The catchment was subject to various studies about hydrological processes (Frey et al., 2009, 2011; Schmocker-Fackel et al., 2007) and pesticide export processes (Leu et al., 2004a, b; Stamm et al., 2004; Freitas et al., 2008) in the past. In this study, process knowledge and sampling data generated by these former studies were used for model set-up and model performance evaluation.

\subsection{Substances and data sources}

The substances in focus of this study were the herbicides Dimethenamid with the TP Dimethenamid OXA (D-OXA), Atrazine with the TP Desethylatrazine (DEA) and Metolachlor with the TP Metolachlor ESA (M-ESA). All three pesticides are mobile substances in water with rather low sorption coefficients (Table 1). The TPs have lower organic carbon sorption coefficients $\left(K_{\mathrm{OC}}\right)$ than their PCs, which indicated that they are more mobile compared to their PCs, especially D-OXA and M-ESA. All TPs of this study are more persistent in the environment than their PCs. The reaction compartment of all TPs is soil (PPDB, 2009), that is, they are usually formed by microbial activity and non-biotic processes such as non-biotic oxidation and hydrolysis.

River sampling data used in this study was taken during a pesticide application experiment in 2000 (Leu et al., 2004a). In this experiment a mixture of pesticides $(8.68 \mathrm{~kg}$ Dimethenamid, $9.62 \mathrm{~kg}$ Atrazine and $4.83 \mathrm{~kg}$ Metolachlor) was applied under controlled conditions at the 8 May 2000 on certain fields (Fig. 1). Subsequently, PC and TP river concentrations and runoff were sampled at three river sampling stations for three months. With this set-up, the influence of unknown pesticide applications on river concentrations could be minimized. Still, some point source influences for Atrazine and Metolachlor were identified. Additionally, Atrazine and Metolachlor were used in previous years in the catchment, which could be seen in the experiment by relatively high baseflow concentrations of these substances. Details on the sampling scheme and analytical methods can be found in Leu et al. (2004b).

\subsection{The model ZIN-AgriTra}

The model used in this study, ZIN-AgriTra, is a further development of the phosphorus export, erosion and hydrological model ZIN-Sed 2D (Gassmann et al., 2013). The main difference to the former model is the introduction of pesticide and TP fate and the modelling of preferential flow by macropores. The model is spatially fully distributed and able to simulate small time steps (minutes-hours).

\subsubsection{Hydrological processes}

Precipitation is conceptualized to fall to an interception storage $I_{\max }$ and the soil surface simultaneously, depending on the fraction $f_{\text {canopy }}$ of a cell covered by the interception storage. Infiltration into the soil matrix is calculated by the Green and Ampt approach (Green and Ampt, 1911), remaining water at the soil surface initiates macropore infiltration or is routed as overland flow.

Water movement within the unsaturated soil matrix is calculated by the Richards equation. The unsaturated hydraulic conductivity and soil water retention are estimated according to the Mualem-Van Genuchten equation (van Genuchten, 1980). An anisotropy factor can be specified to distinguish between the lateral and vertical hydraulic conductivity. The soil consists of three numerical soil layers. Since accuracy of Richards equation may be lowered for water table calculations due to the relatively rough vertical resolution, we added an independent method for the calculation of the groundwater table. Thus, soil moisture within a layer is assumed to increase from field capacity $\theta_{\mathrm{FK}}$ to saturation $\theta_{\mathrm{Sat}}$ with the dimensionless depth $z_{f}$ using a power law function:

$\theta\left(z_{f}\right)=z_{f}^{c} \cdot\left(\theta_{\mathrm{Sat}}-\theta_{\mathrm{FK}}\right)$.

The exponent $c$ is an empirical parameter representing drainage properties of a soil and thus the ability to form a capillary fringe. Integrating Eq. (1) between $z_{f}=0$ and $z_{f}=\mathrm{WT}$ (water table) and considering the upper boundary condition $\theta(0)=\theta_{\mathrm{FK}}$ results in

$\mathrm{WT}=\frac{Q_{\mathrm{sat}}-Q_{\mathrm{act}}}{\theta_{\mathrm{Sat}} \cdot \frac{1}{c+1} \cdot\left(\theta_{\mathrm{FK}}-1\right)-\theta_{\mathrm{FK}}+1}$.

$Q_{\text {act }}$ is the actual water content (mm) and $Q_{\text {sat }}$ the saturated water content $(\mathrm{mm})$. A water table is only calculated for a soil water content above $\theta_{\mathrm{FK}}$. In the model the soil layer establishes a water table successively from bottom layer to top layer. Figure S1b of the Supplement shows the influence of exponent $c$ on the calculation of the water table depth.

The maximum flow velocity in vertical macropores $K_{\mathrm{v}(\mathrm{ma})}$ is calculated by an approach derived from pipe flow using the law of Hagen-Poiseuille, following Wang et al. (1994):

$K_{\mathrm{v}(\mathrm{ma})}=\frac{\pi \cdot g \cdot \rho \cdot\left(\frac{d_{\mathrm{ma}}}{2}\right)^{4}}{8 \cdot v}$,

$g$ is the acceleration due to gravity, $d_{\text {ma }}$ the diameter of the macropore, $v$ the viscosity of water, which is assumed to be constant over time and $\rho$ the water density which is assumed to be unity. The maximum lateral macropore flow velocity 
Table 1. Physico-chemical properties of studied pesticides and their TPs with molar mass M, degradation half-life in soil DT50 soil, organic carbon sorption coefficient $K_{\mathrm{OC}}$ and maximum formation fraction $f f_{\max }$.

\begin{tabular}{lrrrrr}
\hline \multirow{2}{*}{ Substance } & CAS-No. & $M$ & DT50 soil & $K_{\mathrm{OC}}$ & $f f_{\max }$ \\
\cline { 3 - 6 } & & $\left(\mathrm{g} \mathrm{mol}^{-1}\right)$ & $($ days $)$ & $\left(\mathrm{L} \mathrm{kg}^{-1}\right)$ & (weight-\% $)$ \\
\hline Dimethenamid & $87674-68-8$ & 276 & $6^{2}-20^{1}$ & $90^{1}-474^{1}$ & - \\
D-OXA & $380412-59-9$ & 271 & $20^{3}-41^{3}$ & $4^{3}-17^{3}$ & $0.1^{3}$ \\
Atrazine & $1912-24-9$ & 216 & $12^{2}-34^{1}$ & $69^{1}-140^{4}$ & - \\
DEA & $6190-65-4$ & 188 & $33^{4}-45^{5}$ & $38^{6}-76^{4}$ & $0.21^{5}$ \\
Metolachlor & $51218-45-2$ & 284 & $11^{2}-45^{1}$ & $121^{1}-309^{1}$ & - \\
M-ESA & $171118-09-5$ & 351 & $131^{4}$ & $11^{4}$ & $0.1^{5}$ \\
\hline
\end{tabular}

${ }^{1}$ Leu et al. (2004a), ${ }^{2}$ Freitas et al. (2008), ${ }^{3}$ BASF (2005), ${ }^{4}$ Kern et al. (2011), ${ }^{5}$ PPDB (2009), ${ }^{6}$ Bottoni et al. (1996).

$K_{1(\mathrm{ma})}$ is calculated accordingly, taking surface slope $s_{\mathrm{DEM}}$ into account:

$$
K_{1(\mathrm{ma})}=\frac{\pi \cdot g \cdot \rho \cdot\left(\frac{d_{\mathrm{ma}}}{2}\right)^{4}}{8 \cdot v} \cdot \sin \left(\arctan \left(s_{\text {DEM }}\right)\right)
$$

The maximum water transfer per $\mathrm{m}^{2}$ is derived from $K_{\mathrm{v}(\mathrm{ma})}$ and $K_{1(\mathrm{ma})}$ by considering the fraction of laterally connected macropores $f_{\mathrm{ma}}$ and the number of macropores per $\mathrm{m}^{2}$ $n_{\text {Macro }}$. The outflow velocity of water from vertical macropores is calculated by a power law depending on the relative filling of the macropores $\theta_{\mathrm{ma}}$ following the MACRO model (Larsbo et al., 2005):

$q_{\mathrm{ma}}=K_{\mathrm{s}(\mathrm{ma})} \cdot \theta_{\mathrm{ma}}^{n *}$,

$\theta_{\mathrm{ma}}$ is the relative filling of the macropore and $n^{*}$ is an exponent representing macropore size distribution and tortuosity. The outflow from laterally oriented macropores is calculated accordingly. Once water is present in a macropore, it is in interaction with the soil matrix. The infiltration of macropore water into the soil matrix is calculated in the model by a radial Green and Ampt approach following Weiler (2005).

Tile drains are shortcuts for soil water (matrix and macropore) to reach the river and are conceptualized as follows: all vertical subsurface flow in an area affected by tile drains is directly routed to the adjacent river segment (Frey et al., 2009). Lateral soil water is considered to reach the tile drain from two sides:

$q_{\text {drain }}=K_{f} \cdot \frac{\mathrm{WT}_{\text {drain }}}{d_{\text {drain }} / 2} \cdot 2$,

where $q_{\text {drain }}$ is the flow to the drain pipe, $K_{f}$ the saturated hydraulic conductivity, $\mathrm{WT}_{\text {drain }}$ the water table height above the drain pipe and $d_{\text {drain }}$ the distance between drain pipes.

Overland flow is calculated in two dimensions by a diffusive wave approach. The implementation was done in a similar way as presented for the CASC-2D model by Johnson et al. (2000) with the difference that flow is calculated in ZINAgriTra in eight possible flow directions. Flow velocity $u$ is derived with the Manning's equation:

$u=\frac{1}{n_{\mathrm{Man}}} \cdot R_{\mathrm{h}}^{\frac{2}{3}} \cdot s^{\frac{1}{2}}$,

where $R_{\mathrm{h}}$ is the hydraulic radius, $n_{\text {Man }}$ Manning's roughness coefficient and $s$ the friction slope:

$s=s_{\mathrm{DEM}}+\frac{\Delta \mathrm{WT}_{\text {surface }}}{d_{\text {cell }}}$.

$\Delta \mathrm{WT}_{\text {surface }}$ the surface water table difference between two neighbouring cells and $d_{\text {cell }}$ the cell length. Although realistic catchment connectivity should be possible with this set-up, it was shown that changing the grid resolution of a digital elevation model also changes connectivity. Thus, we additionally applied a forcing grid, differentiating areas where overland flow is connected to the river from areas not connected (Frey et al., 2009).

Actual evapotranspiration $\mathrm{ET}_{\mathrm{a}}$ is calculated as the sum of interception storage evaporation $\mathrm{ET}_{\mathrm{int}}$, soil evaporation $\mathrm{ET}_{\text {soil }}$ and plant transpiration $\mathrm{ET}_{\text {plant }}$ :

$\mathrm{ET}_{\mathrm{a}}=\mathrm{ET}_{\text {int }}+\mathrm{ET}_{\text {soil }}+\mathrm{ET}_{\text {plant }}$.

The calculation of $\mathrm{ET}_{\text {int }}$ starts from a value of potential evapotranspiration $\mathrm{ET}_{\mathrm{p}}$ given as input into the model and considers the actual water volume in the interception storage $I_{\text {act }}$ :

$\mathrm{ET}_{\text {int }}=\left\{\begin{array}{c}f_{\text {canopy }} \cdot \mathrm{ET}_{\mathrm{p}} \forall f_{\text {canopy }} \cdot \mathrm{ET}_{\mathrm{p}} \leq I_{\text {act }} \\ I_{\text {act }} \text { otherwise, }\end{array}\right.$

Soil evaporation decreases with soil depth $z$ using the SWAT approach (Neitsch et al., 2011):

$\mathrm{ET}_{\text {soil }}=\left(\left(1-f_{\text {canopy }}\right) \cdot \mathrm{ET}_{\mathrm{p}}\right) \cdot \frac{z}{z+\exp (2.374-0.00713 \cdot z)}$

$\mathrm{ET}_{\text {soil }}$ is calculated for each soil layer using the average depth of the layer from the surface. The fraction of $\mathrm{ET}_{\mathrm{p}}$ which was not evaporated from the interception storage or the soil is 
used for $\mathrm{ET}_{\text {plant }}$ calculations. For this purpose, the root depth $z_{\text {root }}$ and the actual soil moisture $\theta_{\text {act }}$ are considered:

$$
\begin{aligned}
& \mathrm{ET}_{\text {plant }}=C_{\text {crop }} \cdot\left(\mathrm{ET}_{\mathrm{p}}-\mathrm{ET}_{\text {int }}-\mathrm{ET}_{\text {soil }}\right) \cdot \frac{z_{\text {root }}}{z} \cdot \frac{\theta_{\text {act }}-\theta_{\mathrm{PWP}}}{\theta_{\mathrm{FK}}-\theta_{\mathrm{PWP}}} \\
& \forall \theta_{\mathrm{PWP}} \leq \theta_{\text {act }} \leq \theta_{\mathrm{FK}} .
\end{aligned}
$$

$\mathrm{ET}_{\text {plant }}$ is zero below permanent wilting point $\theta_{\mathrm{PWP}}$ and has its maximum between field capacity $\theta_{\mathrm{FK}}$ and saturation. $C_{\text {crop }}$ is the crop coefficient considering variations in the water demand of different land use types (Allen et al., 1998). $\mathrm{ET}_{\text {plant }}$ is calculated in each soil layer according to the root depth in the layer and the soil layer depth.

\subsubsection{Chemical fate processes}

In the ZIN-AgriTra model the mixing layer is incorporated as a thin soil layer interacting with surface runoff. The degradation rate in the mixing layer can be specified independently from the deeper soil layers, representing the influence of both phototransformation and microbial transformation. By infiltration of water previously in contact with the mixing layer, the substance can be transported into the first soil layer and the macropores.

Sorption conceptualization in the model starts from the consideration that dissolved actual concentration $c_{\text {solved }}$ $\left(\mathrm{mg} \mathrm{L}^{-1}\right)$ and adsorbed concentration $c_{\text {adsorbed }}\left(\mathrm{mg} \mathrm{g}^{-1}\right)$ are usually not in equilibrium. Thus, the dissolved equilibrium concentration $c_{\mathrm{e} \text {,solved }}$ is calculated from the sum $c_{\text {total }}$ $\left(\mathrm{mg} \mathrm{L}^{-1}\right)$ of dissolved and adsorbed concentration

$c_{\text {total }}=c_{\text {adsorbed }} \cdot \mathrm{SSC}+c_{\text {solved }}$

and a linear isotherm by

$c_{\mathrm{e}, \text { solved }}=\frac{c_{\mathrm{total}}}{1+f_{\mathrm{OC}} \cdot K_{\mathrm{OC}} \cdot \mathrm{SSC}}$

SSC $\left(\mathrm{g} \mathrm{L}^{-1}\right)$ is the sediment concentration in overland flow or the quotient of soil mass and soil water volume, $K_{\mathrm{OC}}$ is the organic carbon distribution coefficient and $f_{\mathrm{OC}}$ is the fraction of organic carbon in soil. The adsorbed equilibrium concentration $c_{\mathrm{e}, \text { adsorbed }}$ is calculated using Eq. (14) and following the relationship of Eq. (13) by:

$c_{\mathrm{e}, \text { adsorbed }}=\frac{c_{\text {total }}-c_{\mathrm{e}, \text { solved }}}{\mathrm{SSC}}$.

Sorption kinetics is considered in the model by a pseudo firstorder rate equation (Azizian, 2004):

$\frac{\mathrm{d} c_{\text {adsorbed }}}{\mathrm{d} t}=r \cdot\left(c_{\mathrm{e}, \text { adsorbed }}-c_{\text {adsorbed }}\right)$,

where $r$ is the sorption rate constant and $\mathrm{d} t$ the time step. Since adsorption and desorption velocities are usually different, the rate constant $r$ has different values for adsorption $\left(r_{\mathrm{ad}}\right)$ and desorption $\left(r_{\mathrm{de}}\right)$. In the ZIN-AgriTra model, sorption is calculated between soil matrix and soil water, between preferential flow and the surrounding soil, between overland flow and the mixing layer and between overland flow and suspended sediments. Dissolved solutes in macropores are considered to be in contact with and adsorbed to $1 \mathrm{~mm}$ of soil around the macropore.

Pesticide transformation is calculated by a first order degradation approach. The formation of a TP is ruled by the formation fraction $f f_{\mathrm{PC}-\mathrm{TP}}$ as suggested by Kern et al. (2011). The value of $f f_{\mathrm{PC}-\mathrm{TP}}$ integrates the changing molecule mass of the TP and considers the formation of multiple TPs or fractions of total mineralization of the PC. The soil mass balances of PC mass $m_{\mathrm{PC}}$ and TP mass $m_{\mathrm{TP}}$ in the model are

$$
\frac{\mathrm{d} m_{\mathrm{PC}}}{\mathrm{d} t}=m_{\mathrm{app}}-\left(\frac{\ln (2)}{\mathrm{DT} 50_{\mathrm{PC}}} \cdot m_{\mathrm{PC}}\right)-m_{\mathrm{PC}, \text { Runoff }}-m_{\mathrm{PC}, \text { inf }}
$$

and

$$
\begin{aligned}
& \frac{\mathrm{d} m_{\mathrm{TP}}}{\mathrm{d} t}=\left(f f_{\mathrm{PC}-\mathrm{TP}} \cdot \frac{\ln (2)}{\mathrm{DT} 50_{\mathrm{PC}}} \cdot m_{\mathrm{PC}}\right)-\left(\frac{\ln (2)}{\mathrm{DT} 50_{\mathrm{TP}}} \cdot m_{\mathrm{TP}}\right) \\
& \quad-m_{\mathrm{TP}, \text { Runoff }}-m_{\mathrm{TP}, \text { inf }},
\end{aligned}
$$

where $m_{\text {app }}$ is the pesticide mass applied in the field and DT50 ${ }_{\mathrm{PC}}$ and DT50 $\mathrm{TP}$ are the first-order half-life times of the PC and TP, respectively. The mass exported towards the river ( $m_{\mathrm{PC} \text {,Runoff }}$ and $\left.m_{\mathrm{TP} \text {,Runoff }}\right)$ and the mass infiltrating into deeper soil layers or aquifers by matrix and macropores flow ( $m_{\mathrm{PC} \text {,inf }}$ and $m_{\mathrm{TP} \text {,inf }}$ ) are also considered in these equations. Different DT50 were specified in the mixing layer and in the three soil layers. Advection is the only mass transfer process specifically calculated in the model, relying on numerical effects to account for dispersion.

Substances may be exported to the river via lateral macropore and matrix flow, flow to tile drains via macropores and soil matrix and via surface runoff. While in subsurface runoff only dissolved substances are considered, overland flow also transports adsorbed matter. Although ZIN-AgriTra is capable to account for adsorbed matter transport, this pathway was not relevant in the present study since all substances were mobile and, additionally, erosion was not a problem in the Ror catchment.

\subsection{Model set-up}

\subsubsection{Implementation}

Due to the relatively long run times of this model, the code was implemented in $\mathrm{C}++$, using Microsoft Visual Studio 2010. All water and substance flows in the model are solved by an explicit finite differences scheme. The Ror catchment was set up with quadratic cells of 10 metre length and rainfall input time steps of $10 \mathrm{~min}$, which is also the maximum time step of the model calculations. Depending on soil moisture and water table changes from one time step to another, the model time step is adapted to guarantee a stable model run and a closed water balance. The model set-up of this study 
resulted in a model run time of about $2 \mathrm{~h}$ on an Intel ${ }^{\circledR} \mathrm{Core}^{\mathrm{TM}}$ i5-3320M CPU @2.6GHz for a single PC-TP combination.

\subsubsection{Initial conditions and water balance}

There are two main difficulties when modelling short time periods: the choice of initial conditions and the question of the plausibility of the model set-up. In order to get a realistic soil moisture distribution as initial condition for hydrological modelling, we performed a warm-up model run from 1 December 1999-7 May 2000, using rainfall and potential evapotranspiration data from the meteorological station Waedenswil $\left(47^{\circ} 13^{\prime} \mathrm{N}, 8^{\circ} 41^{\prime} \mathrm{E}\right)$. This run was continued until the end of the year 2000 to get the whole water balance of the year and thus check for the plausibility of the model set-up.

Although the pesticide application experiment was the first application in 2000, residues of former applications led to an identifiable baseflow concentration of all substances (Leu et al., 2004b). We adjusted the initial soil mass of pesticide residues in order to match the baseflow concentrations in the eastern subbasin, where substances were assumed to stem solely from subsurface flow (Table 2). The initial masses were spatially and vertically equally distributed in the three soil layers.

\subsubsection{Hydrological parameters}

Rainfall was taken from two sampling stations in the catchment at 10 min resolution (Fig. 1) and spatially distributed, using inverse distance weighting. Potential evapotranspiration was calculated using the FAO crop evapotranspiration method and $C_{\text {crop }}$ were taken from Allen et al. (1998). Other vegetation related parameters were adapted according to the plant parameter database (PlaPaDa, Breuer et al., 2003) or from the SWAT database (Neitsch et al., 2010). Soil hydraulic properties were taken from Frey et al. (2009) and Green and Ampt infiltration parameters were taken from Rawls et al. (1983) or estimated as specified in Maidment (1993) from saturated hydraulic conductivity. The exponent $c$ of Eq. (1) was estimated from the soil water retention curve by assuming a linear distribution of matrix potential from the soil surface to the water table (Fig. S1a) of the Supplement). Most soils in all layers were in a range of $c=2-5$. Only the sand layer in the eastern subbasin had a value of $c=20$. The basic extent of tile drains was available from a map in this study (Fig. 1). However, it was assumed that this map lacks some independently installed drainages. Thus, similar to Frey et al. (2009), we added drainages in sink areas where water was accumulating during rainstorms.

For calculations of macropore flow, the number and diameter of macropores were needed. In Cambisols of the same region, Weiler (2005) determined macropore numbers between 90 and 300 per square metre and macropore diameters between 4 and $6.4 \mathrm{~mm}$. In tilled areas the number of macropores is usually lower due to pore destructions by plough- ing (Beven and Germann, 1982). Thus, we set the number of macropores to 200 per $\mathrm{m}^{2}$ in non-tilled and $100 \mathrm{per} \mathrm{m}^{2}$ in tilled areas. The macropore diameter was set to $4 \mathrm{~mm}$ for all soils. The orientation of macropores in lateral direction depends on the incline of slopes and the underground uniformity. Since slopes were relatively flat, we set the lateral connectivity $f_{\mathrm{ma}}$ to $5 \%$. The macropore distribution index was set to 4, which is a default value in the MACRO model (Larsbo et al., 2005). All soil and vegetation related parameters can be found in Tables S1-S4 of the Supplement.

The catchment boundaries consisted of no-flow boundary conditions for overland flow and lateral subsurface flow. Vertically, the model allowed for an outflow of soil water from the third soil layer towards not connected aquifers. Freitas et al. (2008) reported on groundwater levels in the Ror catchment in 2003. While the levels were rising up to the soil surface in the southern subbasin, levels hardly reacted to rainfall in the eastern subbasin. This was attributed to a sandy subsoil layer, which was able to drain this tributary effectively. We assumed that also the exchange of water across the catchment boundaries was elevated in this region. Therefore, we set the vertical boundary condition in the eastern subbasin to $0.5 \mathrm{~mm} \mathrm{~d}^{-1}$, while the rest of the catchment was considered to be underlain by an impermeable layer.

\subsubsection{Chemical parameters}

Sorption kinetics is often not determined in experimental studies but generally fast for pesticides and faster for adsorption than for desorption (e.g. Shariff, 2011; Baskaran and Kennedy, 1999). We estimated kinetic parameters to be $r_{\mathrm{ad}}=10(1 / \mathrm{d})$ and $r_{\mathrm{de}}=5(1 / \mathrm{d})$. The impact of kinetic parameters on modelling of the main release event can be seen in Fig. S2 of the Supplement. The depth of the mixing layer was set to $2 \mathrm{~cm}$ (Ma et al., 2004). Microbial activity decreases nonlinearly with soil depth. In a soil depth of $80-100 \mathrm{~cm}$ the number of bacteria was found to be about 10-20\% of the surface soil (Tate III, 1979; Susyan et al., 2006). Consequently, the degradation half-life times strongly increase with depth. To account for this increase we multiplied the mixing layer

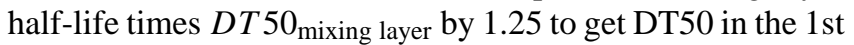
layer (mean of $0-23 \mathrm{~cm}$ ), by 2.0 for the 2 nd layer (mean of $23-58 \mathrm{~cm}$ ) and by $10 \mathrm{for}$ the $3 \mathrm{rd}$ layer (mean of $59-122 \mathrm{~cm}$ ).

\subsubsection{Model calibration}

Due to the relatively long runtimes, the only applicable way for model adaptation to sampled values was a manual calibration. Overall, only few hydrological parameters were calibrated in this study. Evapotranspiration was adapted by changing $C_{\text {crop }}$ in a way that the onset of discharge after the drier period from mid of June 2000 to beginning of July 2000 could be reproduced, resulting in a multiplication of all $C_{\text {crop }}$ values by 1.2 . The soil anisotropy factor was calibrated to 10 , considering the subsurface flow reaction of the catchment to 
Table 2. Calibrated chemical model parameter values. $M_{\text {ini }}$ is the initial soil concentration of substances.

\begin{tabular}{lrrrrrrr}
\hline Substance & $\begin{array}{r}\text { DT50 } \\
\text { mixing layer } \\
(\text { days })\end{array}$ & $\begin{array}{r}\text { DT50 } \\
\begin{array}{l}\text { st layer } \\
(\text { days })\end{array}\end{array}$ & $\begin{array}{r}\text { DT50 } \\
\text { 2nd layer } \\
(\text { days })\end{array}$ & $\begin{array}{r}\text { DT50 } \begin{array}{r}\text { rd layer } \\
(\text { days })\end{array} \\
\begin{array}{r}K_{\text {OC }} \\
\left(\mathrm{L} \mathrm{kg}^{-1}\right)\end{array}\end{array} \begin{array}{r}f f_{\text {PC-TP }} \\
(\text { weight-\% })\end{array}$ & $\begin{array}{r}M_{\text {ini }} \\
\left(\mathrm{g} \mathrm{ha}^{-1}\right)\end{array}$ \\
\hline Dimethenamid & 10 & 13 & 20 & 100 & 140 & - & 0.03 \\
D-OXA & 20 & 26 & 40 & 200 & 10 & 0.04 & 0.05 \\
Atrazine & 16 & 20 & 32 & 160 & 110 & - & 0.27 \\
DEA & 40 & 50 & 80 & 400 & 50 & 0.07 & 0.27 \\
Metolachlor & 20 & 25 & 40 & 200 & 300 & - & 0.53 \\
M-ESA & 131 & 164 & 262 & 1310 & 15 & 0.025 & 0.90 \\
\hline
\end{tabular}

rainfall and the falling limbs of runoff events. The macropore density of the sand layer in the east was calibrated by considering the amount of substance export to the river in the eastern subbasin after the calibration of sorption and transformation parameters. A value of $2 \%$, compared to the other layers, was found. Regarding the chemical fate modules, there is a high possibility of equifinality due to possible parameter correlations (Gassmann et al., 2014). In order to avoid these problems, the basis for calibration of $K_{\mathrm{OC}}$, DT50 mixing layer and $f f_{\mathrm{PC}-\mathrm{TP}}$ were relatively narrow ranges of parameter values found in the literature (Table 1). Sorption coefficients were found to raise or drop the whole substance flux time series whereas complex interactions were found during calibration of PC and TP transformation parameters. Thus, it was not possible to calibrate the PCs and TPs independently but both had to be considered simultaneously.

\subsubsection{Evaluation of model results}

The model was set up to simulate discharge and substance fluxes of the three pesticides and their TPs from 7 May 20001 August 2000. In addition to pesticide residue modelling, a model run was parameterized for the transport of a conservative solute (CS) at the same application rate as Metolachlor. Since a CS is defined to lack sorption and degradation, the model results were used to discuss the influence of environmental fate characteristics on pathways and export masses. In order to determine the influence of substance residues of former applications to export pathways, we performed model runs without soil residues and discussed the results.

The pesticide export modelling results were compared to sampling data at three stations in the Ror catchment, in order to ensure a reasonable spatial prediction (Fig. 1). The performance of the model was evaluated by Nash-Sutcliffe efficiency $\left(N_{\text {eff }}\right)$ (Nash and Sutcliffe, 1970). Since $N_{\text {eff }}$ was shown to have weaknesses for evaluating time series with very high internal variability such as micropollutants (Vezzaro and Mikkelsen, 2012) we additionally calculated the root mean square error (RMSE) and the coefficient of determination $\left(R^{2}\right)$. For an evaluation of the water balance of the year 2000 we had to use literature values since sampling data was restricted to the above mentioned timespan.

\section{Results}

\subsection{Model performance}

The modelled water balance of the Ror catchment for the year 2000 resulted in $1264 \mathrm{~mm}$ rainfall, $519 \mathrm{~mm}$ evapotranspiration, $729 \mathrm{~mm}$ discharge, $3 \mathrm{~mm}$ soil storage change and $12 \mathrm{~mm}$ underground outflow, which may be interpreted as deeper aquifer recharge. The high temporal resolution of the modelled time series shows the huge dynamics of mass fluxes in the catchment over six orders of magnitude (Figs. 2, S3 and S4), whereas discharge ranged over three orders of magnitude. Mass fluxes in the southern subbasin were an order of magnitude higher than mass fluxes in the eastern subbasin. The model was able to reproduce the main export event (No. 6) and the events in the late season at all sampling stations and for all substances. Although small discharge events (events 1-5, 10-11) were underestimated at all stations, discharge was modelled with high values of performance measures (Table 3). Similarly, pollutant losses were underestimated for these events. Nevertheless, goodness-of-fit values suggested a successful modelling for the entire time series at the outlet and in the southern subbasin. In the eastern subbasin $N_{\text {eff }}$ was low for most substances and thus suggested that the model failed in reproducing pesticide residue losses. Still, RMSEs were in the range of only a few $\mathrm{ng} \mathrm{s}^{-1}$ and $R^{2}$ suggested a medium successful but significant modelling of the time series dynamics.

Substance loads were calculated for timespans with available sampling data (Table 4). The model successfully predicted loads at all stations and for all substances except DOXA, which was predicted an order of magnitude too low in the eastern subbasin. Nevertheless, especially the huge difference between the eastern and the southern subbasin was simulated appropriately.

\subsection{Pathway predictions}

The total export of the conservative solute was about $32 \%$ whereas the PCs were only exported between 0.3 and $1.0 \%$ (Table 5). Except DEA, all TPs were recovered in a higher or equal fraction compared to their PCs. At the end of the 

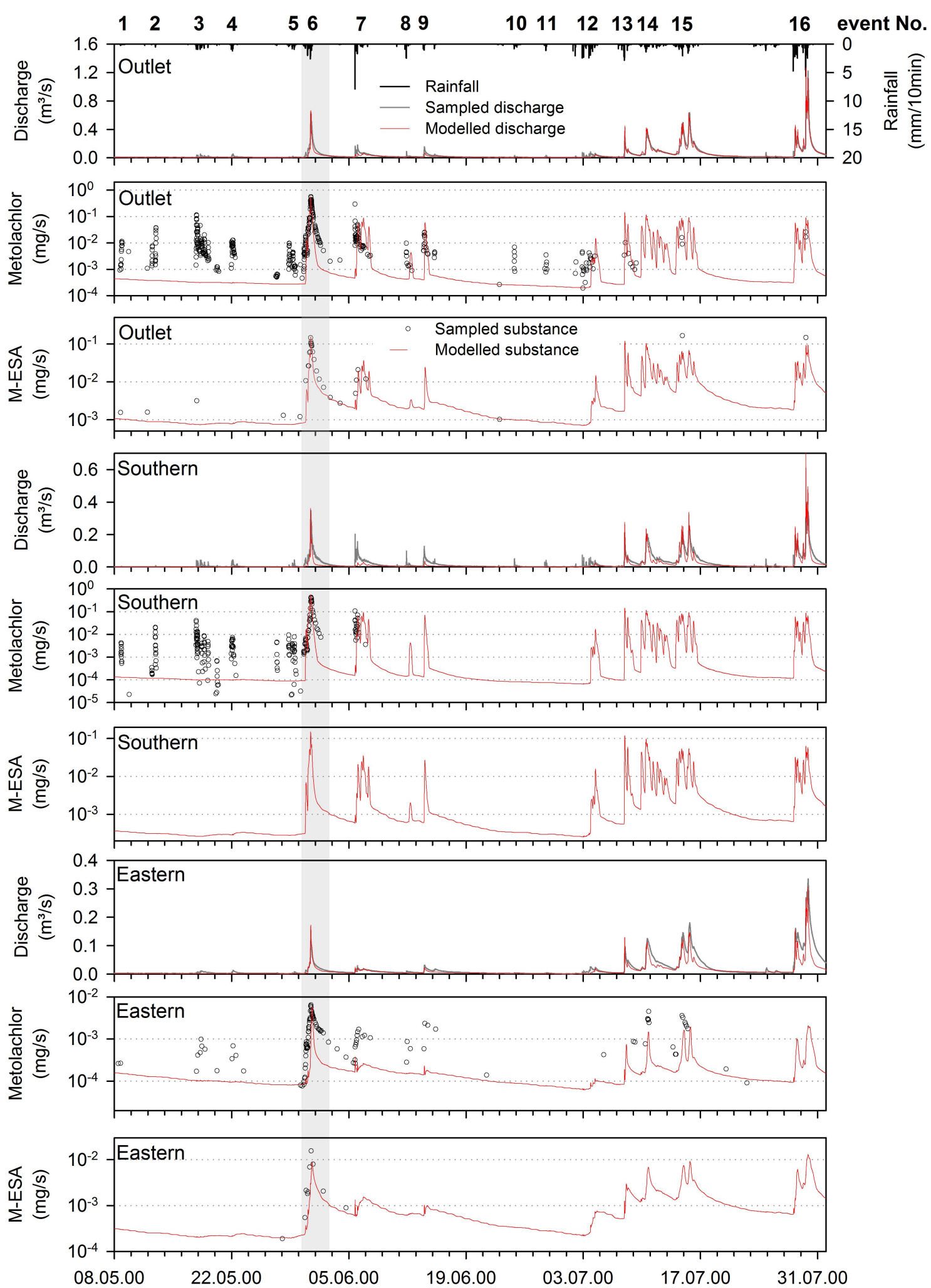

Fig. 2. Modelled and observed discharge, Metolachlor and M-ESA fluxes at all three sampling stations. The main loss event (No. 6) is shaded. 
Table 3. Goodness-of-fit values for pesticide and TP modelling. $n$ is the number of data points involved, $N_{\text {eff }}$ the Nash-Sutcliffe efficiency, RMSE the root mean square error and $R^{2}$ the coefficient of determination ( $p<0.001$ unless otherwise specified).

\begin{tabular}{|c|c|c|c|c|c|c|c|c|c|c|c|c|c|}
\hline \multirow[b]{2}{*}{ Substance } & \multirow[b]{2}{*}{ Unit } & \multicolumn{4}{|c|}{ Outlet } & \multicolumn{4}{|c|}{ Eastern subbasin } & \multicolumn{4}{|c|}{ Southern subbasin } \\
\hline & & $N_{\text {eff }}$ & RMSE & $R^{2}$ & $n$ & $N_{\text {eff }}$ & RMSE & $R^{2}$ & $n$ & $N_{\text {eff }}$ & RMSE & $R^{2}$ & $n$ \\
\hline Discharge & $\mathrm{m}^{3} \mathrm{~s}^{-1}$ & 0.93 & 0.022 & 0.94 & 12240 & 0.80 & 0.015 & 0.88 & 12240 & 0.77 & 0.019 & 0.80 & 12240 \\
\hline D-OXA & $\mathrm{mg} \mathrm{s}^{-1}$ & 0.86 & 0.052 & 0.89 & 33 & -0.02 & 0.008 & $0.55^{*}$ & 10 & - & - & - & - \\
\hline Atrazine & $\mathrm{mg} \mathrm{s}^{-1}$ & 0.81 & 0.170 & 0.84 & 432 & 0.05 & 0.004 & 0.45 & 117 & 0.72 & 0.143 & 0.76 & 243 \\
\hline DEA & $\mathrm{mg} \mathrm{s}^{-1}$ & 0.81 & 0.050 & 0.82 & 33 & 0.43 & 0.001 & 0.66 & 23 & 0.65 & 0.049 & 0.72 & 60 \\
\hline M-ESA & $\mathrm{mg} \mathrm{s}^{-1}$ & 0.69 & 0.028 & 0.73 & 34 & 0.25 & 0.004 & $0.65^{*}$ & 11 & - & - & - & - \\
\hline
\end{tabular}

$* p<0.05$.

Table 4. Sampled and modelled substance loads at the three subbasin outlets.

\begin{tabular}{|c|c|c|c|c|c|c|c|}
\hline & \multicolumn{2}{|c|}{ Outlet } & \multicolumn{2}{|c|}{ Eastern subbasin } & \multicolumn{2}{|c|}{ Southern subbasin } & \multirow[t]{2}{*}{ Timespan } \\
\hline & $\begin{array}{r}\text { Sampled } \\
(\mathrm{g})\end{array}$ & $\begin{array}{r}\text { Modelled } \\
(\mathrm{g})\end{array}$ & $\begin{array}{r}\text { Sampled } \\
(\mathrm{g})\end{array}$ & $\begin{array}{r}\text { Modelled } \\
(\mathrm{g})\end{array}$ & $\begin{array}{r}\text { Sampled } \\
(\mathrm{g})\end{array}$ & $\begin{array}{r}\text { Modelled } \\
(\mathrm{g})\end{array}$ & \\
\hline Dimethenamid & 20.5 & 20.0 & 0.1 & 0.2 & 14.9 & 15.5 & 8 May-14 July 2000 \\
\hline D-OXA & 12.1 & 9.8 & 0.3 & 0.05 & - & - & 8 May-4 June 2000 \\
\hline Metolachlor & 16.2 & 15.3 & 0.7 & 0.2 & 10.7 & 9.7 & 8 May-14 July 2000 \\
\hline M-ESA & 6.8 & 4.5 & 0.3 & 0.1 & - & - & 8 May-4 June 2000 \\
\hline Atrazine & 64.1 & 54.8 & 1.0 & 0.6 & 43.6 & 38.8 & 8 May-14 July 2000 \\
\hline DEA & 10.8 & 9.3 & 0.1 & 0.1 & 7.8 & 7.1 & 8 May-4 June 2000 \\
\hline
\end{tabular}

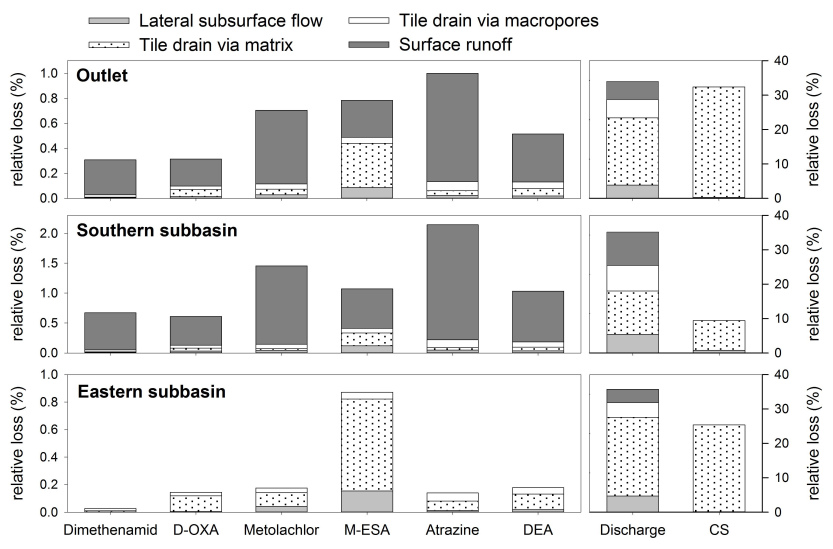

Fig. 3. Modelled contributions of different export pathways to substance export for the whole modelling period at all three stations. The fractions are related to the corresponding sum of applied pesticide mass and initial conditions.

simulation, $67 \%$ of the CS was left in the soil, but only $0.3-$ $5.7 \%$ of the pesticide residues. The pesticides were considered to be mineralized or transformed into not considered TPs to $89-99 \%$. Only the conservative solute had a noticeable transport $(0.3 \%)$ of vertical subsurface export to deeper aquifer layers.
During the modelling period, the three sampling stations behaved differently regarding runoff generation and pesticide residues export (Fig. 3). Surface flow contributed more to total runoff in the southern subbasin and less in the eastern subbasin where slow runoff generation processes prevailed. The relative export of pesticide residues was higher in the southern subbasin than in the eastern subbasin. The CS was exported in all stations almost solely via matrix flow to tile drains but in a much higher fraction in the eastern subbasin, following runoff generation processes. This pathway also prevailed for all pesticide residues in the eastern subbasin except Dimethenamid, which was mainly exported by preferential flow to tile drains. In the southern subbasin, only M-ESA had a considerable export by subsurface processes while the rest was predominantly exported by overland flow. Export at the catchment outlet was a mixture of the other two stations with higher export via subsurface processes than in the southern subbasin, but the main export pathway being overland flow for all substances except M-ESA which had a higher export by matrix flow to tile drains. The contribution of initial soil residues to soil matrix export (lateral and to tile drains) of Metolachlor residues was around $80 \%$ (Fig. 4). $45 \%$ of the total M-ESA export originated from the initial soil residues. The contribution of soil residues to export of all other substances was $0.5-8.5 \%$. 
Table 5. Modelled substance balances at the end of the modelling period. The percentage is related to the sum of application mass and initial soil substance.

\begin{tabular}{lrrrr}
\hline Substance & $\begin{array}{r}\text { River export } \\
(\%)\end{array}$ & $\begin{array}{r}\text { Left in soil } \\
(\%)\end{array}$ & $\begin{array}{r}\text { Mineralized } \\
(\%)\end{array}$ & $\begin{array}{r}\text { Percolation } \\
(\%)\end{array}$ \\
\hline Conservative solute & 32.3 & 67.4 & 0.0 & 0.3 \\
Dimethenamid & 0.3 & 0.3 & 98.7 & 0.0 \\
D-OXA & 0.3 & 0.4 & - & 0.0 \\
Atrazine & 1.0 & 2.6 & 93.6 & 0.0 \\
DEA & 0.5 & 2.4 & - & 0.0 \\
Metolachlor & 0.7 & 5.7 & 89.0 & 0.0 \\
M-ESA & 0.8 & 3.8 & - & 0.0 \\
\hline
\end{tabular}

${ }^{1}$ Includes total mineralization and transformation into not considered transformation products. ${ }^{2}$ Subsurface export of substances from the catchment.

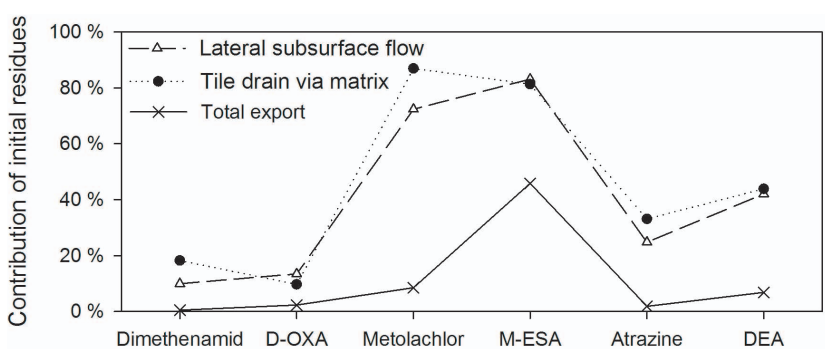

Fig. 4. Modelled contribution of initial residues to substance export pathways at the catchment outlet.

Time series of the different transport processes contributing to substance export and discharge are shown for the main export event (MEE, 23 days after application) and later events (60-71 days after application) in Figs. 5-6 and in the Supplement Figs. S5-S6. The CS mimicked tile drain flow from soil matrix at all sampling stations, but with higher dynamics compared to water discharge. All pesticide residues had sharp export peaks via overland flow but PCs generally had higher overland flow fractions than their TPs. Compared to the MEE, the slower runoff generation processes had larger fractions in the later events in all three stations, which resulted for all substances in higher export fractions by matrix flow to tile drains. Although the fraction of macropore flow decreased in the later events, the fraction of substance export via this pathway increased in the southern subbasin and at the outlet. Only in the eastern subbasin lower fluxes via preferential flow to tile drains were estimated 60-71 days after application. The export via overland flow for the later events decreased in the same way as surface runoff fractions decreased.

The maximum peak fluxes of the CS in the later events were about twofold the peak fluxes of the MEE at the catchment outlet (Fig. 5). Peak fluxes of the PCs towards the end of the study period, however, were only about $5 \%$ (Dimethenamid) and about $20 \%$ (Metolachlor and Atrazine)

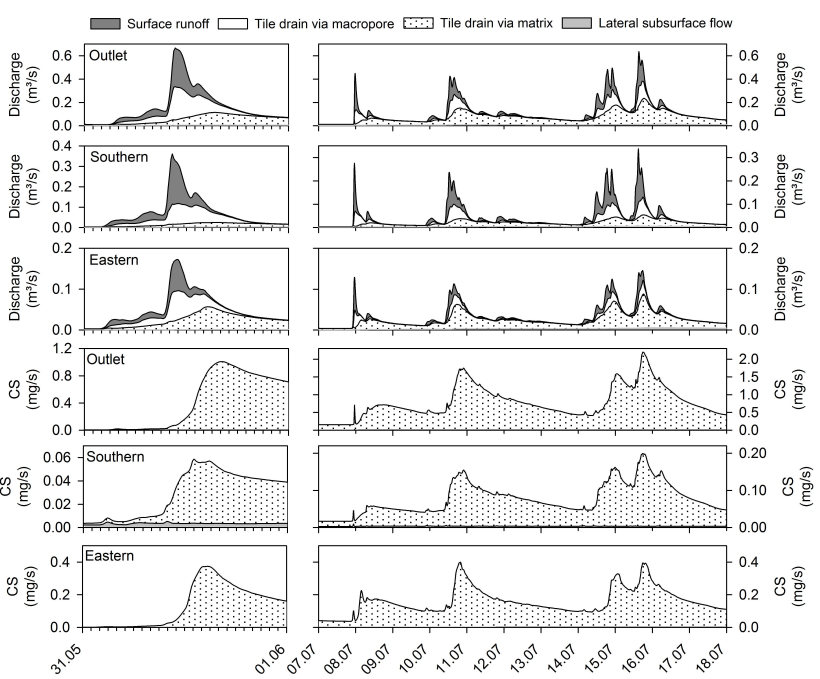

Fig. 5. Modelled pathways of discharge and conservative solute (CS) fluxes reaching the catchment outlet during the main export event (23 days after application) and 60-71 days after application.

of the MEE, while TPs had about $20 \%$ (D-OXA) and about $75 \%$ (DEA and M-ESA).

\section{Discussion}

\subsection{Parametrization}

Due to missing experimental values, sorption kinetics parameters and soil half-lives for deeper soils had to be assessed for this study. We assumed a nonlinear increase of DT50 with depth which was similarly also applied in former studies by Jury et al. (1987) and Ma et al. (2004). Sorption kinetic parameters are rarely determined in experimental studies and only general information is available: kinetics is generally fast for mobile pesticides with most sorption occurring within a few hours (e.g. Locke, 1992), which is equal to firstorder rate coefficients approximately between 10 and $50 \mathrm{~d}^{-1}$. 


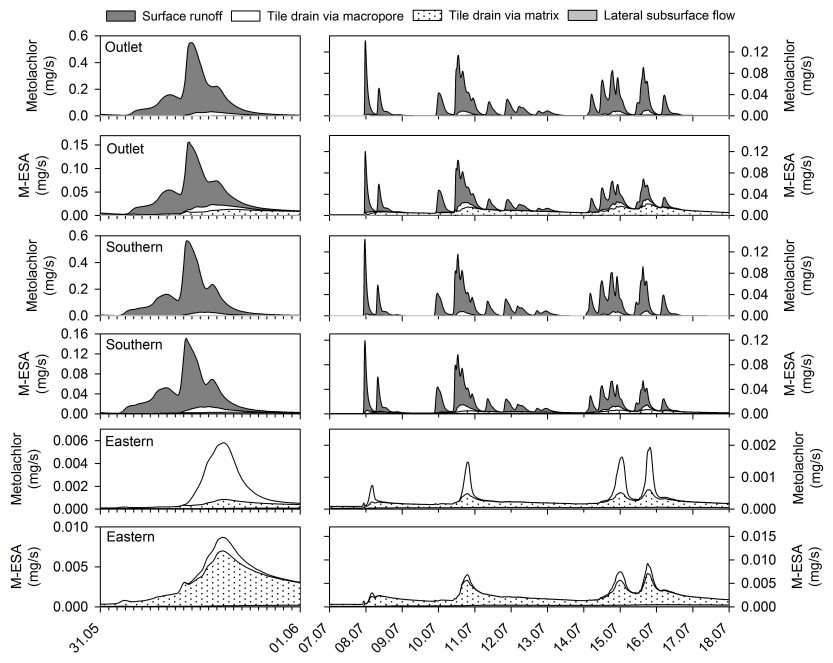

Fig. 6. Modelled pathways of Metolachlor and M-ESA fluxes during the main export event (23 days after application) and 60-71 days after application at all sampling stations.

The chosen sorption kinetic parameters of this study were slower than most values reported in the literature (e.g. $r_{\mathrm{de}}=$ $24 \mathrm{~d}^{-1}$ for Metolachlor, Shariff, 2011). However, considering that literature experiments were conducted using sieved soils, which probably overestimated environmental sorption velocity by neglecting diffusion into soil aggregates and increasing the surface for sorption (Villaverde et al., 2009), our parameter values appear to be reasonable. De Wilde et al. (2008) concluded that rate coefficients were higher for strongly sorbing pesticides, which indicates a correlation between $K_{\mathrm{d}}$ and kinetic parameters. In this study, all pesticides and TPs were rather mobile compounds and thus we considered the rate coefficients to be equal for all substances. Still, we suggest more experimental studies to determine sorption kinetic parameters under realistic environmental conditions in order to reduce associated parameter uncertainty.

The precision of small-scale process conceptualizations suffers from spatial variability of parameter values during upscaling (Gerke et al., 2013). Especially Eq. (3) assumes a simplified macropore geometry and continuity which is never met in reality (Gerke, 2006). Thus, parameters such as $n_{\text {Macro }}$ and $d_{\mathrm{ma}}$ may rather be referred to as "effective" parameters, representing a distribution of macropore numbers and diameters. While many parameters of this study were spatially distributed by using 11 different soil types with three soil layers and 12 land use types (see Tables S1-S4 in the Supplement), the amount of information about macropore parameters was low. Especially organic coatings in macropores may increase adsorption compared to the soil matrix, but there was no information available about this process in the Ror catchment. Thus, we did not account for different organic carbon contents at macropore walls and thus different sorption coefficients as was done by Klaus and Zehe (2011). Still, we in- cluded sorption in macropores by assuming the dissolved solutes to be in contact with $1 \mathrm{~mm}$ of surrounding soil matrix. By varying the depth of surrounding soil which is in contact with macropore solutes, the strength of sorption in macropores may be also varied in our model. Altogether, the contact area and time of pesticides with the sorbent is smaller in macropores and thus the overall retardation is less than in soil matrix (Jarvis, 2007). Furthermore, substance export by macropores was only a minor export pathway in this catchment scale study (Fig. 3).

\subsection{Model performance and uncertainty}

The reasonability of the modelled water balance and the model set-up is confirmed by the fact that mean annual evapotranspiration was estimated before to be in the rage of 500 $550 \mathrm{~mm}$ for this region (Menzel et al., 1999). The highresolution (10 $\mathrm{min})$ goodness-of-fit values point to a largely successful model application for all substances at the outlet and in the southern subbasin, whereas the eastern subbasin exhibited lower performance values. Still, the fluxes were low in the eastern subbasin and thus the absolute errors were low as well. This effect was also observed by Gassmann et al. (2012) when modelling erosion and suspended sediment transport at a high temporal resolution and may be an effect of both, a temporal shift of the model results and an over- or underprediction. Nevertheless, other catchment scale models use a daily resolution (e.g. SWAT, AnnAGNPS), which would not have been able to catch the dynamics of rainfallrunoff events in the Ror catchment. The underestimation of discharge and pollutants during some small events in this study may result from an under-representation of sealed areas like roads and farmyards and the disconnection of these areas from the river in the model, due to the, in this respect, coarse spatial resolution of $10 \mathrm{~m}$. Since it is unlikely that rainfall below $2 \mathrm{~mm}$ (events 1-2) triggers a runoff and pollutant response from agricultural areas, we suppose that the majority of pollutants and water in the small events originated from impervious surfaces. For events 1-5, Leu et al. (2004a) identified farmyard losses for Metolachlor and Atrazine. However, also small amounts of pesticide residues may stem from roads were it was deposited by spray drift during the application. Overall, the events which could not be modelled well were 1-2 orders of magnitude smaller regarding the herbicide loads than the main loss events (event 6-7) and thus only play a minor role for total substance export, which was confirmed by the successful modelling of total export loads (Table 4).

The problem of pesticide residuals from previous years was tackled by introducing an initial uniform soil mass of all substances prior to application, chosen in order to match sampled baseflow concentrations in the eastern subbasin. This led to an overestimation of background concentrations in the southern subbasin, showing that the initial soil mass of substances was rather non-uniformly distributed in the 
catchment. Thus, the initial soil concentrations from Table 2 may only be seen as calibrated parameters and not as real residual amounts in the catchment. To get detailed information about this boundary condition, it would be necessary to take soil samples all over the catchment from different soil depths. Since this would imply a huge workload and financial effort, we suggest a detailed assessment of the importance of the initial condition using baseflow river samples. For larger catchments, a relationship of soil residues to soil texture or crop rotation (Farlin et al., 2013) may help to reduce the workload. Despite the above-mentioned problems with residues and point sources, pesticide application uncertainty, which is common and problematic in pesticide modelling studies (Fohrer et al., 2013), could largely be neglected since detailed information from the farmers about the location and amount of application was available. Some uncertainty may result from the sorption concept used in ZIN-AgriTra. We assumed a linear isotherm to be applicable for the description of the sorption equilibrium, although the Freundlich isotherm was found to produce better fits in experimental sorption studies using organic chemicals (e.g. PPDB, 2009). However, the Freundlich isotherm cannot be solved in analytical form (Frolkovič and Kačur, 2006), necessitating numerical approaches. A numerical solution for the calculation of sorption in each time step and cell would have resulted in too long computation times. Most probably, the effect of using a Freundlich isotherm instead of a linear approach would result in an initially longer tailing of dissolved substances after an event followed by a rapid decline for lower concentrations. Still, the successful modelling of this study suggests that it was in the first hand more important to simulate the correct water pathways than implementing a more complex sorption isotherm for predicting export masses. Furthermore, Stamm et al. (2004) found no tremendous differences between the linear and the Freundlich isotherm for Atrazine, using soils from the Ror catchment.

\subsection{Export and pathway predictions}

Considering only conservative transport, i.e. neglecting sorption and transformation, $67 \%$ of the applied mass would have remained in the soil and about $32 \%$ would have been exported to the river (Table 5). Thus, all deviations from these values could be attributed to the intrinsic physico-chemical properties of the substances and the initial substance masses in the soil. Especially the much lower export fractions of the pesticide residues compared to the CS reflect the influence of sorption and transformation. For PCs, the influence of degradation can be seen in the lower mass fluxes of the later events compared to the MEE. D-OXA was found to be less persistent than the other TPs and the fractions of the later peaks compared to the earlier was therefore only $20 \%$. Still, DOXA had larger peaks in the later season than its PC and Metolachlor and M-ESA had similar high peaks (Fig. 5). Thus, our simulations showed that TPs tend to be exported
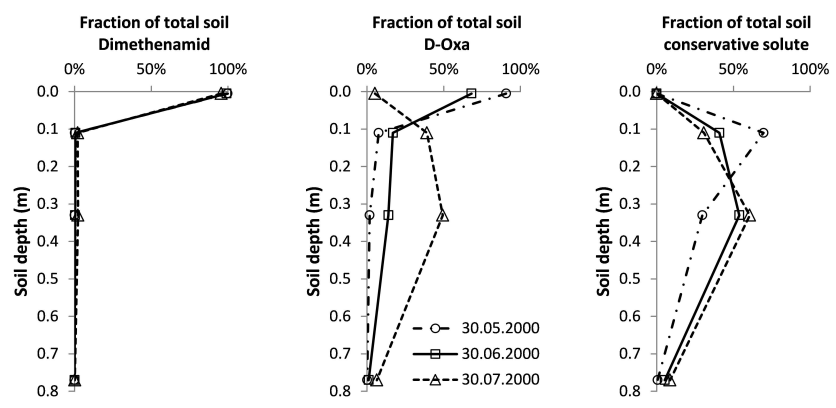

Fig. 7. Modelled distribution of relative Dimethenamid, D-OXA and conservative solute masses in the mixing layer and the matrix of the three soil layers at different time points.

to a higher degree in the later season than their PCs, which was corroborated by field studies before (e.g. Huntscha et al., 2008).

For a validation of pathway predictions it would be necessary to sample water fluxes and solute concentrations of the corresponding pathways. This may be possible for the tile drain system of a catchment by sampling all riverside drainage pipes. However, experimental evidence of differences between contributions of preferential and matrix flow to tile drain export was restricted to the field scale (Johnson et al., 1996). Upscaling to the catchment scale may introduce large uncertainties due to heterogeneities of soil characteristics (Gerke et al., 2013). Similar problems may arise with diffuse river inputs by overland flow and subsurface flow. Although it is generally possible to quantify substance fluxes in overland flow, it may be hard to do so for all significant river channel inputs in a catchment. Even dye tracer experiments, which were recently found to be able to mimic pesticide fate in the environment (Lange et al., 2011), may not be helpful for TP quantification. These problems may be the reason why experimental studies analysing the entire pathway of agrochemicals from application to the river are rare and restricted to small catchments (e.g. Doppler et al., 2012). In this study, missing sampling data of substance export pathways prohibited a direct validation of modelled export processes. Still, the largely successful spatial prediction of substance export and the knowledge about the differences of predominating export processes in the subbasins provided a document of the reasonability of modelled quantities of different export pathways.

Previous studies concluded that lower sorption of agrochemicals results in higher export via overland flow (e.g. Patakioutas and Albanis, 2004). Relative export masses for PCs confirmed this theory (Fig. 3). For TPs, the situation was found to be more complex, since formation fractions, PC half-lives and TP half-lives temporally delay the maximum availability of TPs in the mixing layer. Thus, despite lower $K_{\mathrm{OC}}$ values, overland flow export fractions of TPs were lower than their PCs. The CS was not exported by overland flow at all. This can be explained by the 
hydrological processes of runoff generation: in accordance with Schmocker-Fackel et al. (2007), who studied in detail the runoff generation processes in this catchment, the model calculated overland flow mainly as saturation excess in the Ror catchment. This means that water infiltrated and flushed the non-sorptive CS from the mixing layer into the soil before overland flow was generated (Fig. 7). Thus, at the onset of overland flow, no CS was available for export in the mixing layer.

Various studies reported that lateral subsurface flow may contribute significantly to the export of pesticides (Johnson et al., 1996) and especially TPs during baseflow conditions (Kalkhoff et al., 2003). In our study, only the highly mobile M-ESA showed a considerable amount of export via lateral subsurface flow at the outlet (Fig. 3), which could be assigned to the high amount of initial residues in soil (Fig. 4). We attribute the otherwise low percentage of lateral flow to the gentle slopes in the catchment and low lateral flow velocities in the soil. The modelling timespan may have been too short to find substantial lateral flow contributions from freshly applied pesticides in the river, which is confirmed by the overall low contribution of this pathway to CS export.

Over the whole study period, we found higher soil matrix leaching rates to tile drains for the highly mobile TPs than for their more sorptive PCs (Fig. 3). Similar to lateral subsurface export, initial residues contributed largely to the total export of substances by soil matrix flow to tile drains (Fig. 4). Even the CS and the highly mobile TPs of the freshly applied pesticides reached the third soil layer, in which the tile drains were located, only to a low fraction at the end of the study period (Fig. 7). Still, in combination with the higher DT50 of TPs, the leaching explains the gradually rising export fractions via matrix-fed tile drains for M-ESA and DOXA (Johnson et al., 1996), whereas the less mobile substances remained completely in the mixing layer, even in the late season. Thus, our results are in line with Flury (1996) concluding that leaching of substances through the soil matrix is rather slow and mainly dependent on flow velocity and the substances' sorption properties. The fact that there actually is a contribution of freshly applied substance by matrix flow may be explained by preferential macropore flow and subsequent infiltration into the deeper soil matrix (Lewan et al., 2009).

The exact influence of preferential macropore flow on pesticide export is not yet known (Jarvis, 2007). Although it is seems trivial that vertical preferential flow has the potential to increase substance transport to tile drains, it may also decrease export by bypassing substances which infiltrated into the soil matrix earlier (Larsson and Jarvis, 1999). In this study, leaching due to preferential flow to tile drains increased total tile drain export of PCs by a factor 1-4 while TP export only increased $0.1-0.8$-fold. The total export fraction via preferential flow to tile drains was in the same order of magnitude (0.02-0.07\%) for all substances although their $K_{\mathrm{OC}}$ values differed by a factor 30 and their DT50 by a factor
13. Thus, the importance of the intrinsic pesticide properties seemed to be reduced for vertical preferential flow (Larsson and Jarvis, 2000; Kördel et al., 2008), but total tile drain export increased more for stronger sorbing substances.

The higher export of substances by matrix flow to tile drains in the later events due to increased water flow by this pathway is a document of the importance of the hydrological processes, and especially the contributions of each runoff generation process, for substance export modelling (Holvoet et al., 2005; Cryer and Havens, 1999). Additionally, this effect was stronger for TPs than for PCs. The reason may be that TPs were available in a higher fraction in these later events than PCs due to their delayed formation and longer degradation half-lives. Furthermore, the higher mobility of TPs caused a stronger leaching which resulted in higher availability of TPs in the subsoil for export to tile drains (Fig. 7).

\section{Conclusions}

Earlier simulations of the presence of pesticide residues in river water released from agricultural catchments focused on parent compounds only and the temporal resolution was one day or larger. In this study, we introduced the fate of pesticides and the dynamic formation and fate of TPs into a hydrological model using a high temporal resolution. The model successfully simulated discharge and export of three pesticides and their TPs at three river sampling stations in a headwater catchment. Thus, this application showed that current conceptualizations of transformation processes can be implemented in catchment scale models in order to simulate river export fluxes of TPs. Furthermore, the reasonably good spatial prediction suggests an application of the model for a delineation of critical source areas for pesticide residue export as influenced by their intrinsic substance characteristics.

The model application revealed that the impact of soil residues from former applications on total substance export may be large. Innovative methods are needed to tackle the problem of their quantification and spatial distribution in order to reduce uncertainty of this initial condition. Further, the amount of pesticide export and its pathways were influenced by physico-chemical substance characteristics in this study in a similar way as reported by experimental and modelling studies in the literature. However, the factors influencing TP export were found to be much more complex, since TPs reach their mass peak in the catchment delayed to the PC and all fate parameters of the PC and the TP determine their environmental fate. As a consequence, the importance of single hydrological transport processes was different for PC and TP export. Thus, we conclude that PCs and TPs have generally different export pathways in a catchment due to their different environmental fate characteristics. This fact should be considered in risk assessment for the export of agricultural chemicals to adjacent rivers. Moreover, 
catchment scale models should be extended to include both PCs and TPs.

\section{Supplementary material related to this article is available online at http://www.hydrol-earth-syst-sci.net/ 17/5213/2013/hess-17-5213-2013-supplement.pdf.}

Acknowledgements. We would like to thank Martin Frey for his help with gathering data and the whole Department for Environmental Chemistry at the EAWAG, Dübendorf, for their support during the visit of Matthias Gassmann. The article processing charge was funded by the German Research Foundation (DFG) and the Albert Ludwigs University Freiburg in the funding programme Open Access Publishing. The model was partially developed within the project PhytoRet, funded by the EU Interreg IV programme (project no. C21).

Edited by: E. Zehe

\section{References}

Ahuja, L. R., Sharpley, A. N., Yamamoto, M., and Menzel, R. G.: The depth of rainfall-runoff -soil interaction as determined by 32 P, Water Resour. Res., 17, 969-974, 1981.

Allen, R. G., Pereira, L. S., Raes, D., and Smith, M.: Crop Evapotranspiration - Guidelines for Computing Crop Water Requirements, FAO, Water Resources, Development and Management Service, Rome, Italy, 1998.

Arias-Estévez, M., López-Periago, E., Martínez-Carballo, E., Simal-Gándara, J., Mejuto, J.-C., and García-Río, L.: The mobility and degradation of pesticides in soils and the pollution of groundwater resources, Agr. Ecosyst. Environ., 123, 247-260, 2008.

Azizian, S.: Kinetic models of sorption: a theoretical analysis, J. Colloid Interf. Sci., 276, 47-52, 2004.

BASF: Draft Assessment Report (DAR) - Initial risk assessment provided by the rapporteur Member State Germany for the existing active substance DIMETHENAMID of the second stage of the review programme referred to in Article 8(2) of the Council Directive 91/414/EEC. Volume 3, Annex B, B.8, available at: http://dar.efsa.europa.eu/dar-web/provision/request/subid/35 (last access: 9 January 2013), European Food Safety Authority (EFSA), 2005.

Baskaran, S. and Kennedy, I. R.: Sorption and desorption kinetics of diuron, fluometuron, prometryn and pyrithiobac sodium in soils, J. Environ. Sci. Heal. B, 34, 943-963, 1999.

Beven, K. and Germann, P.: Macropores and water flow in soils, Water Resour. Res., 18, 1311-1325, 1982.

Bottoni, P., Keizer, J., and Funari, E.: Leaching indices of some major triazine metabolites, Chemosphere, 32, 1401-1411, 1996.

Boxall, A. B. A., Sinclair, C. J., Fenner, K., Kolpin, D., and Maund, S. J.: When synthetic chemicals degrade in the environment, Environ. Sci. Technol., 38, 368A-375A, 2004.

Breuer, L., Eckhardt, K., and Frede, H.-G.: Plant parameter values for models in temperate climates, Ecol. Modell., 169, 237-293, 2003.
Brown, C. D. and van Beinum, W.: Pesticide transport via subsurface drains in Europe, Environ. Pollut., 157, 3314-3324, 2009.

Cold, A. and Forbes, V. E.: Consequences of a short pulse of pesticide exposure for survival and reproduction of Gammarus pulex, Aquat. Toxicol., 67, 287-299, 2004.

Craig, J. and Weiss, R.: Use of the gleams model to estimate pesticide overland and subsurface transport in USDA Forest Service nursery applications, Water Sci. Technol., 28, 425-429, 1993.

Cryer, S. A. and Havens, P. L.: Regional sensitivity analysis using a fractional factorial method for the USDA model GLEAMS, Environ. Modell. Softw., 14, 613-624, 1999.

De Wilde, T., Mertens, J., Spanoghe, P., Ryckeboer, J., Jaeken, P., and Springael, D.: Sorption kinetics and its effects on retention and leaching, Chemosphere, 72, 509-516, 2008.

Doppler, T., Camenzuli, L., Hirzel, G., Krauss, M., Lück, A., and Stamm, C.: Spatial variability of herbicide mobilisation and transport at catchment scale: insights from a field experiment, Hydrol. Earth Syst. Sci., 16, 1947-1967, doi:10.5194/hess-161947-2012, 2012.

Farlin, J., Gallé, T., Bayerle, M., Pittois, D., Braun, C., El Khabbaz, H., Lallement, C., Leopold, U., Vanderborght, J., and Weihermueller, L.: Using the long-term memory effect of pesticide and metabolite soil residues to estimate field degradation half-life and test leaching predictions, Geoderma, 207-208, 15-24, 2013.

Flanagan, D. C., Zuercher, B. W., and Huang, C.-H.: AnnAGNPS application and evaluation in NE Indiana, in: American Society of Agricultural and Biological Engineers Annual International Meeting 11, 085112, St. Joseph, Michigan, 2008.

Flury, M.: Experimental evidence of transport of pesticides through field soils - a review, J. Environ. Qual., 25, 25-45, 1996.

Fohrer, N., Dietrich, A., Kolychalow, O., and Ulrich, U.: Assessment of the environmental fate of the herbicides flufenacet and metazachlor with the SWAT model, J. Environ. Qual., 42, 1-11, 2013.

Fox, G. A., Sabbagh, G. J., Malone, R. W., and Rojas, K.: Modeling parent and metabolite fate and transport in subsurface drained fields with directly connected macropores, J. Am. Water Resour. As., 43, 1359-1372, 2007.

Freitas, L. G., Singer, H., Müller, S. R., Schwarzenbach, R. P., and Stamm, C.: Source area effects on pesticide losses to surface waters - a case study in the Swiss Plateau, Agr. Ecosyst. Environ., 128, 177-184, 2008.

Frey, M. P., Schneider, M. K., Dietzel, A., Reichert, P., and Stamm, C.: Predicting critical source areas for diffuse pesticide losses to surface waters: role of connectivity and boundary conditions, J. Hydrol., 365, 23-36, 2009.

Frey, M. P., Stamm, C., Schneider, M. K., and Reichert, P.: Using discharge data to reduce structural deficits in a hydrological model with a Bayesian inference approach and the implications for the prediction of critical source areas, Water Resour. Res., 47, W12529, doi:10.1029/2010WR009993, 2011.

Frolkovič , P. and Kačur, J.: Semi-analytical solutions of a contaminant transport equation with nonlinear sorption in $1 \mathrm{D}$, Comput. Geosci., 10, 279-290, 2006.

Gassmann, M., Lange, J., and Schuetz, T.: Erosion modelling designed for water quality simulation, Ecohydrology 5, 269-278, 2012. 
Gassmann, M., Brito, D., and Olsson, O.: Estimation of phosphorus export from a Mediterranean agricultural catchment with scarce data, Hydrolog. Sci. J., doi:10.1080/02626667.2013.798661, in press, 2013.

Gassmann, M., Khodorkovsky, M., Friedler, E., Dubowski, Y., and Olsson, O.: Uncertainty in the river export modelling of pesticides and transformation products, Environ. Modell. Softw., 51, 35-44, 2014.

Gerke, H. H.: Preferential flow descriptions for structured soils, J. Plant Nutr. Soil Sci., 169, 382-400, 2006.

Gerke, H. H., Dusek, J., and Vogel, T.: Solute Mass Transfer Effects in Two-Dimensional Dual-Permeability Modeling of Bromide Leaching From a Tile-Drained Field, Vadose Zone J., 12, 1-1, doi:10.2136/vzj2012.0091, 2013.

Gouy, V., Dur, J.-C., Calvet, R., Belamie, R., and Chaplain, V.: Influence of adsorption- desorption phenomena on pesticide runoff from soil using simulated rainfall, Pestic. Sci., 55, 175-182, 1999.

Green, W. H. and Ampt, G. A.: Studies of soil physics. I. The flow of air and water through soils, J. Agr. Sci., 4, 1-24, 1911.

Hladik, M. L., Domagalski, J. L., and Kuivila, K. M.: Concentrations and loads of suspended sediment-associated pesticides in the San Joaquin River, California and tributaries during storm events, Sci. Total Environ., 408, 356-364, 2009.

Holvoet, K., van Griensven, A., Seuntjens, P., and Vanrolleghem, P. A.: Sensitivity analysis for hydrology and pesticide supply towards the river in SWAT, Phys. Chem. Earth, 30, 518-526, 2005.

Holvoet, K., van Griensven, A., Gevaert, V., Seuntjens, P., and Vanrolleghem, P. A.: Modifications to the SWAT code for modelling direct pesticide losses, Environ. Modell. Softw., 23, 72-81, 2008.

Huntscha, S., Singer, H., Canonica, S., Schwarzenbach, R. P., and Fenner, K.: Input dynamics and fate in surface water of the pesticide metolachlor and of its highly mobile transformation product metolachlor ESA, Environ. Sci. Technol., 42, 5507-5513, 2008.

Jarvis, N. J.: A review of non-equilibrium water flow and solute transport in soil macropores: principles, controlling factors and consequences for water quality, Eur. J. Soil Sci., 58, 523-546, 2007

Johnson, A. C., Haria, A. H., Bhardwaj, C. L., Williams, R. J., and Walker, A.: Preferential flow pathways and their capacity to transport isoproturon in a structured clay soil, Pestic. Sci., 48, 225-237, 1996.

Johnson, B. E., Julien, P. Y., Molnar, D. K., and Watson, C. C.: The two-dimensional upland erosion model CASC2D-SED, J. Am. Water Resour. As., 36, 31-42, 2000.

Jury, W. A., Focht, D. D., and Farmer, W. J.: Evaluation of pesticide groundwater pollution potential from standard indices of soil-chemical adsorption and biodegradation, J. Environ. Qual., 16, 422-428, 1987.

Kalkhoff, S. J., Lee, K. E., Porter, S. D., Terrio, P. J., and Thurman, E. M.: Herbicides and pesticide degradation products in upper midwest agricultural streams during august base flow conditions, J. Environ. Qual., 32, 1025-1035, 2003.

Kannan, N., White, S. M., Worrall, F., and Whelan, M. J.: Pesticide modelling for a small catchment using SWAT-2000, J. Environ. Sci. Heal. B, 41, 1049-1070, 2006.

Kern, S., Singer, H., Hollender, J., Schwarzenbach, R. P., and Fenner, K.: Assessing exposure to transformation products of soilapplied organic contaminants in surface water: comparison of model predictions and field data, Environ. Sci. Technol., 45, 2833-2841, 2011.

Kladivko, E. J., van Scoyoc, G. E., Monke, E. J., Oates, K. M., and Pask, W.: Pesticide and nutrient movement into subsurface tile drains on a silt loam soil in Indiana, J. Environ. Qual., 20, 264 270, 1991.

Klaus, J. and Zehe, E.: A novel explicit approach to model bromide and pesticide transport in connected soil structures, Hydrol. Earth Syst. Sci., 15, 2127-2144, doi:10.5194/hess-15-21272011, 2011.

Kördel, W., Egli, H., and Klein, M.: Transport of pesticides via macropores (IUPAC technical report), Pure Appl. Chem., 80, 105-160, 2008.

Lange, J., Schuetz, T., Gregoire, C., Elsässer, D., Schulz, R., Passeport, E., and Tournebize, J.: Multi-tracer experiments to characterise contaminant mitigation capacities for different types of artificial wetlands, Int. J. Environ. Anal. Chem., 91, 768-785, 2011.

Larsbo, M., Roulier, S., Stenemo, F., Kasteel, R., and Jarvis, N.: An improved dual-permeability model of water flow and solute transport in the vadose zone, Vadose Zone J., 4, 398-406, 2005.

Larsson, M. H. and Jarvis, N. J.: Evaluation of a dual-porosity model to predict field-scale solute transport in a macroporous soil, J. Hydrol., 215, 153-171, 1999.

Larsson, M. H. and Jarvis, N. J.: Quantifying interactions between compound properties and macropore flow effects on pesticide leaching, Pest. Manag. Sci., 56, 133-141, 2000.

Leu, C., Singer, H., Stamm, C., Müller, S. R., and Schwarzenbach, R. P.: Simultaneous assessment of sources, processes, and factors influenicing pesticide losses to surface waters in a small agricultural catchment, Environ. Sci. Technol., 38, 3827-3834, $2004 \mathrm{a}$.

Leu, C., Singer, H., Stamm, C., Müller, S. R., and Schwarzenbach, R. P.: Variability of pesticide losses from 13 fields to surface water within a small catchment after a controlled pesticide application, Environ. Sci. Technol., 38, 3835-3841, 2004b.

Lewan, E., Kreuger, J., and Jarvis, N.: Implications of precipitation patterns and antecedent soil water content for leaching of pesticides from arable land, Agr. Water Manage., 96, 1633-1640, 2009.

Limousin, G., Gaudet, J.-P., Charlet, L., Szenknect, S., Barthès, V., and Krimissa, M.: Sorption isotherms: a review on physical bases, modeling and measurement, Appl. Geochem., 22, 249275, 2007.

Locke, M. A.: Sorption-desorption kinetics of alachlor in surface soil from two soybean tillage systems, J. Environ. Qual., 21, 558566, 1992.

Ma, Q., Wauchope, R. D., Ma, L., Rojas, K. W., Malone, R. W., and Ahuja, L. R.: Test of the Root Zone Water Quality Model (RZWQM) for predicting runoff of atrazine, alachlor and fenamiphos species from conventional-tillage corn mesoplots, Pest Manag. Sci., 60, 267-276, 2004.

Maidment, D. R.: Handbook of Hydrology, McGraw-Hill, New York, 1993.

Menzel, L., Lang, H., and Rohmann, M.: Mittlere jährliche aktuelle Verdunstungshöhen 1973-1992, Hydrologischer Atlas der Schweiz (HADES), Bundesamt für Umwelt (BAFU), Switzerland, Bern, 1999. 
Nash, J. and Sutcliffe, J.: River flow forecasting through conceptual models part I - a discussion of principles, J. Hydrol., 10, 282290, 1970.

Neitsch, S., Arnold, J., Kiniry, J., Srinivasan, R., and Williams, J.: SWAT2009 Input/Output File Documentation, Texas Water Ressources Institute Technical Report No. 406, Temple, Texas, 2010.

Neitsch, S., Arnold, J., Kiniry, J., and Williams, J. R.: SWAT2009 Theoretical Documentation, Texas Water Ressources Institute Technical Report No. 406, Temple, Texas, 2011.

Olsson, O., Khodorkovsky, M., Gassmann, M., Friedler, E., Schneider, M., and Dubowski, Y.: Fate of pesticides and their transformation and products: first flush effects in a semi-arid catchment, Clean-Soil Air Water, 41, 134-142, 2013.

Patakioutas, G. I. and Albanis, T. A.: Runoff of pesticides from cropped and uncropped plots with different slopes, Int. J. Environ. Anal. Chem., 84, 103-121, 2004.

PPDB: The Pesticide Properties Database (PPDB), Agriculture and Environment Research Unit (AERU), University of Hertfordshire, funded by UK national sources and the EU-funded FOOTPRINT project (FP6-SSP-022704), University of Hertfordshire, 2009.

Rawls, W. J., Brakensiek, D. L., and Miller, N.: Green-ampt inflltration parameters from soils data, J. Hydraul. Eng., 109, 62-70, 1983.

Rosenbom, A. E., Kjær, J., Henriksen, T., Ullum, M., and Olsen, P.: Ability of the MACRO model to predict long-term leaching of metribuzin and diketometribuzin, Environ. Sci. Technol., 43, 3221-3226, 2009.

Schmocker-Fackel, P., Naef, F., and Scherrer, S.: Identifying runoff processes on the plot and catchment scale, Hydrol. Earth Syst. Sci., 11, 891-906, doi:10.5194/hess-11-891-2007, 2007.

Schulz, R.: Comparison of spray drift- and runoff -related input of azinphos-methyl and endosulfan from fruit orchards into the Lourens River, South Africa, Chemosphere, 45, 543-551, 2001.

Shariff, R. M.: Thermodynamic adsorption-desorption of metolachlor and 2,4-D on agricultural soils, Int. J. Chem., 3, 134-146, 2011.

Shipitalo, M. J. and Owens, L. B.: Atrazine, deethylatrazine, and deisopropylatrazine in surface runoff from conservation tilled watersheds, Environ. Sci. Technol., 37, 944-950, 2003.
Singh, N., Kloeppel, H., and Klein, W.: Movement of metolachlor and terbuthylazine in core and packed soil columns, Chemosphere, 47, 409-415, 2002.

Stamm, C., Waul, C., Leu, C., Freitas, L. G., Popow, G., Singer, H., and Muller, S.: Sorption effects on herbicide losses to surface waters in a small catchment of the Swiss Plateau, Z. Planzenk. Planzen., 19, 951-958, 2004.

Susyan, E. A., Rybyanets, D. S., and Ananyeva, N. D.: Microbial activity in the profiles of gray forest soil and chernozems, Eurasian Soil Sci. +, 39, 859-867, 2006.

Tang, X., Zhu, B., and Katou, H.: A review of rapid transport of pesticides from sloping farmland to surface waters: processes and mitigation strategies, J. Environ. Sci., 24, 351-361, 2012.

Tate III, R. L.: Microbial activity in organic soils as affected by soil depth and crop, Appl. Environ. Microbiol., 37, 1085-1090, 1979.

Traub-Eberhard, U., Kördel, W., Klein, W.: Pesticide movement into subsurface drains on a loamy silt soil, Chemosphere, 28 , 273-284, 1994.

van Genuchten, M. T.: A closed-form equation for predicting the hydraulic conductivity of unsaturated soils, Soil Sci. Soc. Am. J., 44, 892-898, 1980.

Vezzaro, L. and Mikkelsen, P. S.: Application of global sensitivity analysis and uncertainty quantification in dynamic modelling of micropollutants in stormwater runoff, Environ. Modell. Softw., 27-28, 40-51, 2012.

Villaverde, J., van Beinum, W., Beulke, S., and Brown, C. D.: The kinetics of sorption by retarded diffusion into soil aggregate pores, Environ. Sci. Technol., 43, 8227-8232, 2009.

Wang, D., Norman, J. M., Lowery, B., and McSweeney, K.: Nondestructive determination of hydrogeometrical characteristics of soil macropores, Soil Sci. Soc. Am. J., 58, 294-303, 1994.

Weiler, M.: An infiltration model based on flow variability in macropores: development, sensitivity analysis and applications, J. Hydrol., 310, 294-315, 2005.

Zehe, E. and Flühler, H.: Preferential transport of isoproturon at a plot scale and a field scale tile-drained site, J. Hydrol., 247, 100$115,2001$. 